Forestry and Grassland

Received on: $20 / 11 / 2020$

Accepted on: 25/03/2021

\title{
Chemical composition of Tanganyika grass under tree shading levels in a silvopastoral system
}

Composição química do capim-tanganica submetido a níveis de sombreamento arbóreo em sistema silvipastoril

${ }^{1}$ CARVALHO, Carlos Augusto Brandão de https://orcid.org/0000-0002-1096-5370

\author{
${ }^{2 *}$ SILVA, Pedro Henrique Ferreira da \\ https://orcid.org/0000-0002-0794-4499 \\ ${ }^{3}$ ZANELLA, Pablo Giliard \\ https://orcid.org/0000-0003-1348-8001
}

${ }^{1}$ Federal Rural University of Rio de Janeiro, Institute of Animal Science, Seropédica, Rio de Janeiro 23890-000, Brazil

${ }^{2}$ Federal Rural University of Pernambuco, Department of Animal Science, Recife, Pernambuco 51171-900, Brazil

${ }^{3}$ University of Santa Catarina State, Animal Science - Campus Chapecó, Chapecó, Santa Catarina 89815-630, Brazil

*Mail for correspondence: pehenrique1709@gmail.com

\begin{abstract}
This study aimed to evaluate the effect of different Clitoria fairchildiana tree shading levels on the Tanganyika grass (Megatyrsus maximus Jacq. cv. Tanganyika) chemical composition, in summer I (2011/2012), spring (2012) and summer II (2012/2013) seasons. For this purpose, an experiment was conducted in a completely randomized design with four treatments (shading levels) and five repetitions at Seropédica, state of Rio de Janeiro, Brazil. The following variables were evaluated: dry matter (DM), crude protein (CP), neutral detergent (NDF) and acid detergent (ADF) fiber, neutral (NDIP) and acid (ADIP) detergent insoluble protein, lignin (LIG) and mineral matter (MM) contents. Data were analyzed by PROC MIXED SAS ${ }^{\circledR}$, with repeated measures in time, and treatment means compared by Tukey's test $(\mathrm{P}<0.05)$ or by PROC REG $(\mathrm{P}<0.05$ for regression analysis. There was a significant interaction between season and shading level for DM, CP, NDF, ADF, NDIP, ADIP and MM contents $(\mathrm{P}<0.05)$. Lignin content was only influenced by shading level $(\mathrm{P}<0.05)$. The DM, NDF, ADF and lignin contents were reduced by shading increase while CP, NIDP and MM contents were increased. Higher ADIP contents were found only in the spring. The increase in Clitoria fairchildiana tree shading improves the chemical composition of Tanganyika grass forage during summer season.
\end{abstract}

Keywords: crude protein, insoluble protein, Megathyrsus maximus, neutral detergent fiber, shadow. 


\section{RESUMO}

O objetivo deste trabalho foi avaliar o efeito de diferentes níveis de sombreamento arbóreo da espécie Clitoria fairchildiana sobre a composição bromatológica do capimtanganica (Megatyrsus maximus Jacq. cv. Tanganica), nas estações do verão I (2011/2012), primavera (2012) e verão II (2012/2013). Para tanto, foi instalado um experimento sob delineamento inteiramente casualizado, com quatro tratamentos (níveis de sombreamento) e cinco repetições em Seropédica, Rio de Janeiro, Brasil. Foram avaliados os teores de: matéria seca (MS), proteína bruta (PB), fibra em detergente neutro (FDN) e em detergente ácido (FDA), proteína insolúvel em detergente neutro (PIDN) e em detergente ácido (PIDA), lignina (LIG) e matéria mineral (MM). Os dados foram analisados pelo PROC MIXED do SAS ${ }^{\circledR}$, com medidas repetidas no tempo, e as médias dos tratamentos comparadas pelo teste de Tukey $(\mathrm{P}<0,05)$; ou pelo PROC REG do SAS ${ }^{\circledR}$ para as análises de regressão $(\mathrm{P}<0,05)$. Houve efeito de interação entre nível de sombreamento e estação do ano para teores de MS, PB, FDN, FDA, PIDN, PIDA e MM. Os teores de lignina foram influenciados apenas pelo nível de sombreamento. Os teores de MS, FDN, FDA e lignina foram reduzidos, enquanto aqueles de PB, PIDN e MM aumentaram linearmente em função dos níveis de sombreamento. Maiores teores de PIDA foram verificados somente na primavera. O aumento do sombreamento arbóreo de Clitoria fairchildiana melhora a composição bromatológica da forragem do capimtanganica, durante o verão.

Palavras-chave: fibra insolúvel em detergente neutro, Megatyrsus maximus, proteína bruta, proteína insolúvel, sombra.

\section{INTRODUCTION}

Brazil has a cattle herd estimated at 172.2 million of animals, besides 149,670,217 hectares of grasslands (ABIEC, 2020). Thereby, there is a pressure for a more sustainable livestock and a consequent demand for integrated production, like silvopastoral systems (LIMA et al., 2013). The success of these systems also depends on the choice of forage species, which should present resistance and adaptation to tree shading, besides high forage quality and productivity (LIMA et al., 2020).

In silvopastoral systems, light radiation is lower under the treetops, which influences the morphogenetic traits of productivity and the nutritional value of forage (LIMA et al., 2018). Thus, tolerance to shading will depend on the

morphophysiological adaptation of the plant to the reduced levels of light radiation (PACIULLO et al., 2017a).

The search of Megatyrsus maximus Jacq. for silvopastoral systems has been increased, because this species shows a large genetic variability that allows selection of shading tolerant genotypes (VICTOR et al., 2015; PACIULLO et al., 2017). The Tanganyika cultivar, whose origin center is Occidental Africa, has a short size $(1.20$ to $1.50 \mathrm{~m})$, thin stem (1.0 to $1.5 \mathrm{~cm}$-thickness) and narrower leaves than other genotypes from the species (ALCÂNTARA \& BUFARAH, 1980). These morphological aspects suggest that this cultivar presents better nutritional value and higher shading tolerance than other 
cultivars as Tanzania and Mombaça grasses (SILVA et al., 2018)

Shading exerts a positive effect on the nutritional value of harvested forage. Lower photosynthetic efficiency by plants and lower evapotranspiration of plant-soil system occur (TAIZ et al., 2017). Therefore, there is a lower growth and the plant tissues present more cell content, besides thin and less lignified cell walls (SANTOS et al., 2019). Paciullo et al (2017a) evaluated the nutritional value of Tanzania grass (Megatyrsus maximus cv. Tanzania) forage and observed an increase of $54 \mathrm{~g}$ $\mathrm{kg}^{-1}$ in the CP content as function of shading increase from zero to $58 \%$. Moreover, Wong et al. (1985) classified the Tanganyica grass (Megatyrsus maximus Jacq. cv. Tanganyica) as shading tolerant due to its productivity and morphological composition (PEREIRA et al., 2015).

Based on this context, this study aimed to evaluate the effect of Clitoria fairchildiana shading level on the chemical composition of Tanganyica grass, during the summer I (2010/2011), spring (2011) and summer II $(2011 / 2012)$ seasons.

\section{MATERIAL AND METHODS}

The experiment was carried out at the Experimental Field of Animal Nutrition, Grasslands Department, Animal Science Institute from Federal Rural University of Rio de Janeiro (DNAP/IZ - UFRRJ), municipality of Seropédica- RJ, $22^{\circ} 45^{\prime}$ $\mathrm{S}, 43^{\circ} 41^{\prime} \mathrm{W}$, at 33 meters altitude. The climate of the region is Aw (KÖPPEN, 1828), with dry season lasting from April to September, and rainy season lasting from October to March. Climate data during the experimental period (Figure 1) were obtained from INMET (2013).

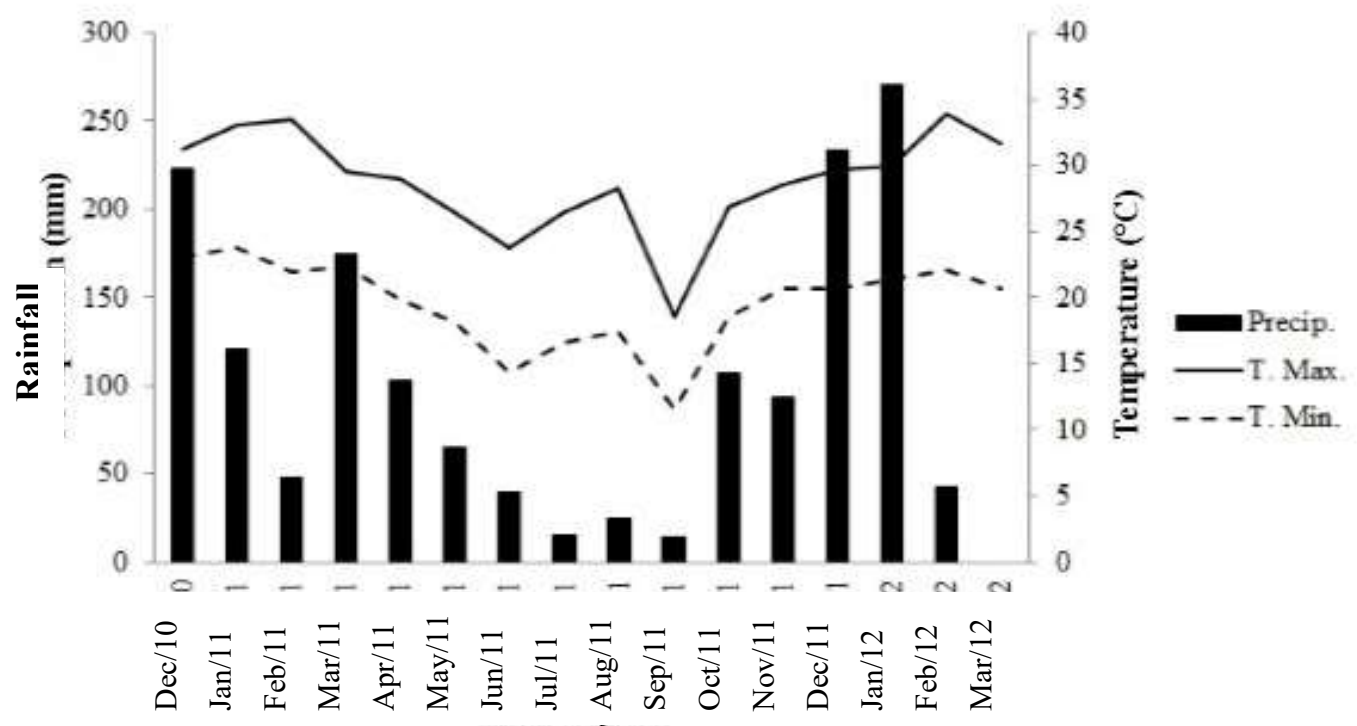

Figure 1. Maximum (T. Max.) and minimum (T. Min.) temperature, besides the average monthly rainfall (Rainfall) recorded during the experimental period. Source: SeropédicaAgricultural Ecology-A60 Station, Seropédica- RJ. 
Tanganyika grass was planted in 20 plots (experimental units) with $8.0 \mathrm{~m}^{2}$ each, on March 2010. Maintenance fertilizations were done with $200 \mathrm{~kg} \mathrm{ha}^{-1}$ year $^{-1} \mathrm{~N}$ and $\mathrm{K}_{2} \mathrm{O}$ using urea and potassium chloride as sources. Fertilizers were equally divided in five applications: three in spring and summer; the remaining two in fall and winter. Phosphate fertilizer was also applied on $11 / 23 / 2010$, with $80 \mathrm{~kg}$ $\mathrm{ha}^{-1} \mathrm{P}_{2} \mathrm{O}_{5}$ using simple superphosphate.

The experiment was conducted in the seasons of summer I $(12 / 27 / 2010$ to $03 / 20 / 2011)$, the spring $(09 / 02 / 2011$ to $12 / 20 / 2011)$ and the summer II $(12 / 21 / 2011$ to $03 / 01 / 2020)$. Historically, these seasons have important climatic differences as to the average rainfall and temperature (ALCÂNTARA \& SCHUELER, 2015). Treatments consisted of the average shading levels evaluated under treetops of Clitoria fairchildiana, commonly known as "sombrero" or "cow's shadow". The trees already existed in the 0.5 hectares of pasture over than 15 years, with 20 trees randomly dispersed, a fact that allowed stratified shading intensities in the experimental area. Below the trees, areas that presented homogeneous shading levels were selected, sites in which the experimental units (plots) were allocated.

Shading levels were weekly evaluated under the trees at 9:00 a.m., 12:00 p.m. and 3:00 p.m., using the canopy analyzer AccuPAR Linear PAR/LAI ceptometer, Model PAR - 80 in 12 points below the trees and above the forage canopy of each plot, and described as averages of the three evaluated seasons (Table 1). These shading levels were classified as slight (SS), mild (MS) and heavy (HS). Moreover, Tanganyika grass was also evaluated under full sun (FS) condition as the control treatment. The experiment was conducted in a completely randomized design with five repetitions. Photosynthetic active radiations (PAR) above the treetops in the summer I, spring and summer II were 1,564, 1,307 and $1,776 \mu \mathrm{mol} \mathrm{m}^{-2} \mathrm{~s}^{-1}$, respectively.

Forage samples were harvested in the plots, inside a frame of $0.25 \mathrm{~m}^{2}(0.5 \times 0.5$ $\mathrm{m})$ that was positioned at the center of each plot and $15 \mathrm{~cm}$ above the ground, when the average light interception (LI) of the forage canopy reached $95 \%$. For this purpose, 12 measures of LI per plot were taken simultaneously below (at the ground level) and above the forage canopy, on a weekly frequency and, thereafter, at 2-day frequency when the average LI was $90 \%$ or more.

The chemical composition of Tanganyika grass was evaluated through the dry matter (DM), neutral (NDF) and acid (ADF) detergent-insoluble fiber, crude protein $(\mathrm{CP})$, mineral matter (MM) and lignin (LIG) contents, according to Silva \& Queiroz (2012) and Detmann et al. (2012). Neutral (NDIP) and acid (ADIP) detergent-insoluble protein contents were determined according to Licitra et al. (1996).

Data were analyzed by PROC MIXED from SAS $^{\circledR}$ version 9.3 (SAS, 2008), with repeated measures in time. The shading level, season of year and their interactions were considered fixed effects. The variance and covariance matrices were selected by the Akaike's information criterion (AKAIKE, 1974). Means were compared by Tukey's test, and the PROC REG from SAS ${ }^{\circledR}$ analyzed the quantitative data by simple linear regression, under probability error of $5 \%$. 
Table 1. Average levels of Clitoria fairchildiana shading on Tanganyika grass canopy in the seasons of summer I (201/2011), spring (2011) and summer II (2011/2012).

\begin{tabular}{lcccc}
\hline \multirow{2}{*}{ Season } & \multicolumn{4}{c}{ Shading level } \\
\cline { 2 - 5 } & FS (\%) & SS (\%) & MS (\%) & HS (\%) \\
\hline Summer I & 0 & 26 & 46 & 54 \\
Spring & 0 & 27 & 54 & 59 \\
Summer II & 0 & 31 & 47 & 56 \\
\hline
\end{tabular}

FS: full sun; SS: slight shading; MS: mild shading; HS: heavy shading.

\section{RESULTS AND DISCUSSION}

There was an interaction effect between shading level and season of year for DM and MM contents of Tanganyika grass forage (Table 2). The DM contents were higher during the summer II at full sun (FS), during the spring in the slight shading (SS), similar between the seasons for the mild shading (MS) and higher during the summer I for the heavy shading (HS). During the summer I, the DM contents were similar between the shading levels (average of $226.0 \mathrm{~g} \mathrm{~kg}^{-1}$ ), and were linearly reduced $(\mathrm{P}<0.05)$ during the spring and summer II. This was possibly because of the highest mean values of shadings verified in SS, MS and HS for the spring and summer II, in comparison to those shadings of summer I (Table 2).

Sousa et al. (2010) also observed a decreasing DM content in marandu grass (Urochloa brizantha Syn. cv. Marandu) according to tree shading, from 294 to $258 \mathrm{~g} \mathrm{~kg}^{-1}$. The authors justified these results due to the highest proportion of leaves in forage harvested from the shaded pastures, because high shade levels promote lower water losses by leaf tissues, which increases the moisture content and consequently reduces the dry matter content (SANTOS et al., 2019).

The MM content were higher in the summer I for all shading treatments, and for spring and summer II the observed values were similar (Table 2). There were linear increases in MM content as a function of shading levels, in all seasons $(\mathrm{P}<0.05)$, which is beneficial to animal nutrition due to the higher concentration of essential minerals in the available forage for the animals, such as $\mathrm{Ca}, \mathrm{P}, \mathrm{K}$ and $\mathrm{Mg}$ (BROUDER et al., 2020). Although the light does not act directly on the uptake of minerals by plants, it affects some biological processes such as respiration, transpiration and photosynthesis, which can indirectly reduce the MM content in shaded forage plants (REIS et al, 2013). 
Table 2. Dry matter (DM) and mineral matter (MM) of M. maximus cv. Tanganyika under the evaluated tree shading levels and seasons of the year.

\begin{tabular}{|c|c|c|c|c|c|c|c|}
\hline \multirow{2}{*}{ Season } & \multicolumn{4}{|c|}{ Shading level ${ }^{1}(\%)$} & \multirow{2}{*}{ SEM } & \multirow{2}{*}{ Regression equation } & \multirow{2}{*}{$\mathrm{R}^{2}$} \\
\hline & FS & SS & MS & $\mathrm{HS}$ & & & \\
\hline \multicolumn{8}{|c|}{$\mathrm{DM}\left(\mathrm{g} \mathrm{kg}^{-1}\right)$} \\
\hline Summer I & $258.0 \mathrm{~b}$ & $214.0 \mathrm{ab}$ & $207.0 \mathrm{a}$ & $226.0 \mathrm{a}$ & 17.3 & $\hat{\mathrm{Y}}=226.0^{\mathrm{ns}}$ & - \\
\hline Spring & $249.0 \mathrm{~b}$ & $247.0 \mathrm{a}$ & $194.0 \mathrm{a}$ & $181.0 \mathrm{~b}$ & 3.3 & $\hat{Y}=259.6-1.195 X^{* *}$ & 0.80 \\
\hline Summer II & $313.0 \mathrm{a}$ & $210.0 \mathrm{~b}$ & $188.0 \mathrm{a}$ & $172.0 \mathrm{~b}$ & 12.9 & $\hat{\mathrm{Y}}=298.8-2.433 \mathrm{X}^{* *}$ & 0.86 \\
\hline \multicolumn{8}{|c|}{$\mathrm{MM}\left(\mathrm{g} \mathrm{kg}^{-1}\right)$} \\
\hline Summer I & $91.0 \mathrm{a}$ & $106.0 \mathrm{a}$ & $123.0 \mathrm{a}$ & $122.0 \mathrm{a}$ & 2.6 & $\hat{\mathrm{Y}}=90.69+0.449 \mathrm{X}^{*}$ & 0.84 \\
\hline Spring & $78.0 \mathrm{~b}$ & $72.0 \mathrm{~b}$ & $100.0 \mathrm{~b}$ & $103.0 \mathrm{~b}$ & 2.5 & $\hat{\mathrm{Y}}=71.57+0.477 \mathrm{X}^{*}$ & 0.62 \\
\hline Summer II & $68.0 \mathrm{c}$ & $70.0 \mathrm{~b}$ & $95.0 \mathrm{~b}$ & $103.0 \mathrm{~b}$ & 2.4 & $\hat{\mathrm{Y}}=64.51+0.679 \mathrm{X}^{*}$ & 0.78 \\
\hline
\end{tabular}

${ }^{1}$ Values respectively described in Table 1 for each season of year. FS: full sun; SS: slight shading; MS: mild shading; HS: heavy shading. The seasons of year occurred between the following dates: summer I from 12/27/2010 to 03/20/2011; spring occurred from 09/02/2011 to 12/20/2011 and summer II from 12/21/2011 to $03 / 01 / 2012$. X: percentage of shade. Means followed by different letters in the same column are significantly different by Tukey's test $(\mathrm{p}<0.05)$. SEM: standard error of the mean. ${ }^{*}(\mathrm{p}<0.05),{ }^{* *}(\mathrm{p}<0.01)$ and ns: nonsignificant.

The increase in MM content found in the present experiment indicates the Tanganyika grass as a potential forage resource that should be more studied for animal nutrition, especially when grown under shading.

Lower NDF and ADF contents were found in summer I compared to spring and summer II $(\mathrm{P}<0.05)$ at FS (Table 3$)$. For the SS, NDF contents were lower in the summer II compared to the other seasons, and there was similarity between these seasons for the AFD content. For MS, lower values of NDF and ADF were observed in the spring, while in the most shaded treatment (HS), the lowest NDF value was found in the spring. The increment in shading levels promoted a similar effect for NDF and ADF, with linear reduction $(\mathrm{P}<0.01)$ for both variables only in the spring, besides non-significant difference between the summers II and I.

Santiago-Hernandéz et al. (2016) also observed a decrease in ADF content (from 312 to $310 \mathrm{~g} \mathrm{~kg}^{-1}$ ), to compare the Tanzania and Mombaça grasses under full sun with those grown under tree shading.

Both reducing of NDF and ADF contents, especially that related to spring season (Table 3), can be explained by the probably lower growth rate of plants under shading, due to the light restriction (PACIULLO et al., 2017b). With lower growth under these conditions, the plant tissues present more cell content, besides less thick and lignified cell walls (SANTOS et al., 2019). 
Table 3. Insoluble neutral (NDF) and acid detergent fiber (ADF) contents of M. maximus cv. Tanganyika under the evaluated tree shading levels and seasons of the year.

\begin{tabular}{|c|c|c|c|c|c|c|c|}
\hline \multirow[b]{2}{*}{ Season } & \multicolumn{4}{|c|}{ Shading level $^{1}(\%)$} & \multirow{2}{*}{ SEM } & \multirow{2}{*}{ Regression equation } & \multirow{2}{*}{$\mathrm{R}^{2}$} \\
\hline & FS & $\mathrm{SS}$ & MS & SS & & & \\
\hline \multicolumn{8}{|c|}{ NDF $\left(\mathrm{g} \mathrm{kg}^{-1}\right)$} \\
\hline Summer I & $649.0 b$ & $665.0 \mathrm{a}$ & $645.0 \mathrm{a}$ & $650.0 \mathrm{a}$ & 8.4 & $\hat{\mathrm{Y}}=653.0^{\mathrm{ns}}$ & - \\
\hline Spring & $668.0 \mathrm{a}$ & $666.0 \mathrm{a}$ & $588.0 \mathrm{~b}$ & $618.0 \mathrm{~b}$ & 4.0 & $\hat{\mathrm{Y}}=675,74-1.238 \mathrm{X}^{* *}$ & 0,80 \\
\hline Summer II & $669.0 \mathrm{a}$ & $636.0 \mathrm{~b}$ & $639.0 \mathrm{a}$ & $662.0 \mathrm{a}$ & 4.8 & $\mathrm{Y}=651.0^{\mathrm{ns}}$ & - \\
\hline \multicolumn{8}{|c|}{$\operatorname{ADF}\left(\mathrm{g} \mathrm{kg}^{-1}\right)$} \\
\hline Summer I & $350.0 \mathrm{~b}$ & $346.0 \mathrm{a}$ & $334.0 \mathrm{a}$ & $340.0 \mathrm{ab}$ & 5.4 & $\hat{\mathrm{Y}}=342.0^{\mathrm{ns}}$ & - \\
\hline Spring & $378.0 \mathrm{a}$ & $346.0 \mathrm{a}$ & $327.0 \mathrm{~b}$ & $348.0 \mathrm{a}$ & 3.9 & $\hat{\mathrm{Y}}=377,78-01.132 \mathrm{X}^{* *}$ & 0,86 \\
\hline Summer II & $367.0 \mathrm{a}$ & $344.0 \mathrm{a}$ & $353.0 \mathrm{a}$ & $348.0 \mathrm{a}$ & 4.3 & $\mathrm{Y}=353.0^{\mathrm{ns}}$ & - \\
\hline
\end{tabular}

${ }^{1}$ Values described in Table 1 for each season of the year. FS: full sun; SS: soft shading; MS: moderate shading; SS: strong shading. The seasons of year occurred between the following dates: summer I from 12/27/2010 to 03/20/2011; spring occurred from 09/02/2011 to $12 / 20 / 2011$ and summer II from 12/21/2011 to $03 / 01 / 2012$. X: percentage of shade. Means followed by equal letters in the same column do not differ each other by the Tukey test $(\mathrm{p}<0.05)$. SEM: standard error of mean. $*(\mathrm{p}<0.05),{ }^{* *}(\mathrm{p}<0.01)$ and ns: not significant.

There was an interaction effect between shading level and season for CP, NDIP and ADIP contents of Tanganyika grass forage (Table 4). The CP contents did not differ between seasons for FS, and did not present a defined pattern of behavior. The increasing levels of shading promoted a linear response of $\mathrm{CP}$ content $(\mathrm{P}<0.01)$ for all seasons, fact that corroborates Gobbi et al. (2010) and Sousa et al. (2010) that also found increasing of $\mathrm{N}$ content in the plant tissues due to the light restriction.

Under shade, the plant presents lower growth rate, as previously mentioned, and this contributes to the increasing cell content compared to the plant cell wall (SANTOS et al., 2019). However, it is important to considerer that shading reduces the evapotranspiration of plant-soil system and the $\mathrm{N}$ volatilization from soil
(LEMAIRE et al., 2011; MARSCHNER, 2012). These factors may have increased the $\mathrm{CP}$ content; because of the increasing of shading levels (Table 4) and considering that $200 \mathrm{~kg} \mathrm{ha}^{-1}$ year $^{-1} \mathrm{~N}$ were applied as urea source.

Nevertheless, not all protein contained in the plant tissue can be used as nutrient for ruminants. Part of crude protein can be linked to fiber fractions of the forage (LICITRA et al., 1996). This explains why there was a linear increase $(\mathrm{P}<0.01)$ in NDIP contents as a function of shading levels, in all seasons of the year. On the other hand, the NDIP contents of Tanganyika grass forage were similar between seasons in the FS and lower for the SS in the spring, compared to both summer seasons. For MS and HS, the lowest values were verified in the summer II. 
Table 4. Crude protein (CP), neutral (NDIP) and acid (ADIP) detergent insoluble protein contents of $M$. maximus cv. Tanganyika under the evaluated tree shading levels and seasons of the year.

\begin{tabular}{|c|c|c|c|c|c|c|c|}
\hline \multirow[b]{2}{*}{ Season } & \multicolumn{4}{|c|}{ Shading level $^{1}(\%)$} & \multirow{2}{*}{ SEM } & \multirow{2}{*}{ Regression equation } & \multirow{2}{*}{$\mathrm{R}^{2}$} \\
\hline & FS & SS & MS & $\mathrm{HS}$ & & & \\
\hline \multicolumn{8}{|c|}{$\mathrm{CP}\left(\mathrm{g} \mathrm{kg}^{-1}\right)$} \\
\hline Summer I & $60.0 \mathrm{a}$ & $83.0 \mathrm{~b}$ & $108.0 \mathrm{a}$ & $123.0 \mathrm{a}$ & 3.7 & $\hat{\mathrm{Y}}=56.92+0.822 \mathrm{X}^{* *}$ & 0.83 \\
\hline Spring & $69.0 \mathrm{a}$ & $72.0 \mathrm{c}$ & $94.0 \mathrm{~b}$ & $104.0 \mathrm{~b}$ & 3.7 & $\hat{\mathrm{Y}}=64.65+0.583 \mathrm{X}^{* *}$ & 0.67 \\
\hline Summer II & $70.0 \mathrm{a}$ & $99.0 \mathrm{a}$ & $98.0 \mathrm{ab}$ & $110.0 \mathrm{~b}$ & 3.7 & $\hat{\mathrm{Y}}=77.84+0.573 \mathrm{X}^{* *}$ & 0.57 \\
\hline \multicolumn{8}{|c|}{$\operatorname{NDIP}\left(\mathrm{g} \mathrm{kg}^{-1}\right)$} \\
\hline Summer I & $34.0 \mathrm{a}$ & $48.0 \mathrm{a}$ & $64.0 \mathrm{~b}$ & $85.0 \mathrm{a}$ & 2.1 & $\hat{\mathrm{Y}}=30.67+0,607 \mathrm{X}^{* *}$ & 0.80 \\
\hline Spring & $31.0 \mathrm{a}$ & $32.0 \mathrm{~b}$ & $62.0 \mathrm{a}$ & $65.0 \mathrm{~b}$ & 3.9 & $\hat{\mathrm{Y}}=50.13+0.634 \mathrm{X}^{* *}$ & 0.65 \\
\hline Summer II & $28.0 \mathrm{a}$ & $51.0 \mathrm{a}$ & $53.0 \mathrm{~b}$ & $56.0 \mathrm{c}$ & 2.8 & $\hat{\mathrm{Y}}=34.56+0.423 \mathrm{X} * *$ & 0.54 \\
\hline \multicolumn{8}{|c|}{$\operatorname{ADIP}\left(\mathrm{g} \mathrm{kg}^{-1}\right)$} \\
\hline Summer I & $21.0 \mathrm{a}$ & $22.0 \mathrm{a}$ & $24.0 \mathrm{a}$ & $24.0 \mathrm{a}$ & 1.2 & $\hat{\mathrm{Y}}=23,0^{\mathrm{ns}}$ & - \\
\hline Spring & $12.0 \mathrm{~b}$ & $13.0 \mathrm{~b}$ & $21.0 \mathrm{a}$ & $22.0 \mathrm{a}$ & 1.2 & $\hat{\mathrm{Y}}=11,22+0,156 \mathrm{X}^{*}$ & 0.76 \\
\hline Summer II & $13.0 \mathrm{~b}$ & $18.0 \mathrm{ab}$ & $15.0 \mathrm{~b}$ & $20.0 \mathrm{~b}$ & 1.3 & $\mathrm{Y}=17,0^{\mathrm{ns}}$ & - \\
\hline
\end{tabular}

${ }^{1}$ Values respectively described in Table 1 for each season of year. FS: full sun; SS: soft shading; MS: moderate shading; SS: strong shading. The seasons of year occurred between the following dates: summer I from 12/27/2010 to 03/20/2011; spring occurred from 09/02/2011 to 12/20/2011 and summer II from 12/21/2011 to 03/01/2012. X: percentage of shade. Means followed by different letters in the same column are significantly different by Tukey's test $(\mathrm{p}<0.05)$. SEM: standard error of the mean. ${ }^{*}(\mathrm{p}<0.05),{ }^{* *}(\mathrm{p}<0.01)$ and ns: non-significant.

The ADIP contents were lower in the summer II for all treatments, and similar in the spring under FS. There was a linear increase $(\mathrm{P}<0.05)$ of $11.2 \mathrm{~g} \mathrm{~kg}^{-1}$ ADIP for each shade percentage unity only in the spring, while this variable did not altered in both summer seasons in function of the highest shading levels (Table 4).

Therefore, under the shading effect, the Tanganyika grass presented a greater amount of protein linked to NDF (in all seasons) than adhered to ADF (only in spring), probably because the lignin contents $(\mathrm{P}<0.05)$ were linearly reduced with increasing shading levels, and the ADIP is quite linked to this indigestible fiber carbohydrate (SNIFFEN et al., 1992).

NDIP represents the protein fraction linked to the plant cell wall that is moderately digestible and slowly degraded in rumen (Fraction $\mathrm{B}_{3}$ ), while ADIP represents the protein fraction that is practically indigestible, also adhered to this cell wall (LICITRA et al., 1996). The fact that ADIP content increased only in spring season, while CP content increased in all ones, suggests that there was a moderate increment in protein digestibility of Tanganyika grass as function of increasing shading levels (HENRIQUES et al., 2007), at least in summers II and I.

Paciullo et al. (2017a) evaluated the ADIP contents of Massai grass under three shading levels $(0 ; 37$ and 58\%) and observed an increase of $30 \mathrm{~g} \mathrm{~kg}^{-1}$ in this protein fraction because of light restriction. The authors pointed that shading did not result in an effective improvement of the forage nutritional 
value, because there was an accumulation of indigestible protein in the chemical composition. On the other hand, in the present study, as mentioned before, possibly there was a moderate increase in the nutritional value of Tanganyika grass.

There was only shading effect $(\mathrm{P}<0.01)$ for the lignin content, with a linear decrease as a function of shading level. The average values observed for the shading levels were: 58.26, 54.14, 51.05 and $50.02 \mathrm{~g} \mathrm{~kg}^{-1}$ for FS, SS, MS and HS, respectively. The regression equation was $\left[\hat{\mathrm{Y}}\left(\mathrm{g} \mathrm{kg}^{-1}\right)=58.26-0.147 \%\right.$ shade and the coefficient of determination $\left(\mathrm{R}^{2}\right)$ was 0.59 .

Paciullo et al. (2007) found no differences between lignin content of Urochloa decumbens Stapf., when it was grown under the full sun compared to under reduced light. On the other hand, Baldassini et al. (2018) observed a little increase of $4 \%$ forage digestibility of Gatton Panic (Megatyrsus maximus Jacq. cv. Gatton Panic) under tree shading in the Argentinian Chaco region, compared to the full sun. This evidences that there are differences in the nutritional value between forage species subjected to shading, and this can arouse the interest for Tanganyika grass exploitation in silvopastoral systems, due to positive effect of light restriction on lignin content.

\section{CONCLUSIONS}

Tree shading and the seasons of year together influence the chemical variables of Tanganyika grass forage.

The increase in shading level improves crude protein content and results in moderate digestible protein fractions of Tanganyika grass during the spring and the summer seasons, at the same time that increases indigestible fractions in the spring.

The nutritional composition of Tanganyika grass shows improvement under intense shading in the summer season.

\section{REFERENCES}

AKAIKE, H. A new look at the statistical model identification. IEEE transactions on automatic control, v.19, n.6, p.716-723, 1974.

ALCÂNTARA, P.B.; BUFARAH, G. Plantas forrageiras: gramíneas e leguminosas. São Paulo, Nobel, 1980.

ASSOCIAÇÃO BRASILEIRA DAS INDÚSTRIAS EXPORTADORAS DE CARNES (ABIEC). Beef report Perfil da pecuária no Brasil, 2020. Disponível em: http://abiec.com.br/publicacoes/beefreport-2020/.

BALDASSINI, P.; DESPÓSITO, C.; PIÑEIRO, G. et al. Silvopastoral systems of the Chaco foreSS: Effects of trees on grass growth. Journal of Arid Environments, v.156, p.87-95. 2018.

BROUDER, S.M.; VOLENEC, J.J. Mineral Nutrient Acquisition and Metabolism. In: MOORE, K.J..; COLLINS, M.; NELSON, C.J. et al. Forages: The Science of Grassland Agriculture Volume II, p.85-111, 2020.

DETMANN, E., SOUZA, M.D., VALADARES FILHO, S.D.C. et al. Métodos para análise de alimentos - 
INCT - Ciência Animal. Visconde do Rio Branco, MG: Suprema, 2012.

GOBBI, K.F., GARCÍA, R., GARCEZ NETO, A.F. et al. Valor nutritivo do capim-braquiária e do amendoim forrageiro submetidos ao sombreamento. Archivos de Zootecnia, v.59, n.227, p.379-390, 2010 .

HENRIQUES, L.T., DETMANN, E., QUEIROZ, A.C. et al. Frações dos compostos nitrogenados associados à parede celular em forragens tropicais. Arquivo Brasileiro de Medicina Veterinária e Zootecnia, v.59, n.1, p.258-263, 2007.

INSTITUTO NACIONAL DE METEOROLOGIA (INMET). Dados Climatológicos, Estação Automática de Seropédica, 2013. Disponível em: http://www.inmet.gov.br.

KÖPPEN, W.; GEIGER, R. Klimate der Erde. Gotha: Verlag Justus Perthes, 1928.

LEMAIRE, G. HODGSON, J.; CHABBI, A. (Ed.). Grassland productivity and ecosystem services. Oxford: CABI, 2011.

LICITRA, G.; HERNANDEZ, T.M.; VAN SOEST, P.J. Standardization of procedures for nitrogen fractionation of ruminant feeds. Animal Feed Science and Technology, v.57, n.4, p.347-358, 1996.

LIMA, H.N.; DUBEUX JÚNIOR; J.C.B.; SANTOS, M.V. et al. Herbage responses of signalgrass under full sun or shade in a silvopasture system using tree legumes. Agronomy Journal, v.112, n.3, p.1-10, 2020.

LIMA, M.A.; PACIULLO, D.S.C.; MORENZ, M.J.F. et al. Productivity and nutritive value of Brachiaria decumbens and performance of dairy heifers in a long-term silvopastoral system. Grass and Forage Science, v.74, n.1, p.160-170, 2018.

LIMA, P.R.; MALAVASI, U.C.; ECCO, M. et al. Espécies lenhosas nativas com potencial de uso em sistema silvipastoril em Mato Grosso do Sul. Revista Agrogeoambiental, v.5, n.2, 2013.

\section{MARSCHNER, P. Marschner's mineral nutrition of higher plants. London: Academic Press, 2012.}

PACIULLO, D.S.C.; CARVALHO, C A.B.; AROEIRA, L.J.M. Morfofisiologia e valor nutritivo do capim-braquiária sob sombreamento natural e a sol pleno. Pesquisa

Agropecuária Brasileira, v.42, n.4, p.573-579, 2007.

PACIULLO, D.S.C.; GOMIDE, C.D.M.; CASTRO, C.R.T.

Morphogenesis, biomass and nutritive value of Panicum maximum under different shade levels and fertilizer nitrogen rates. Grass and Forage Science, v.7, n.3, p.590-600, 2017.

PACIULLO, D.S.; PIRES, M.F.; MÜLLER, M.D. et al. Oportunidades e desafios dos sistemas integrados na produção animal: ênfase nos sistemas silvipastoris. Archivos Latinoamericanos de Producción Animal, v.25, p.25-35, 2017. 
REIS, G.L.; EMERENCIANO NETO, J.V.; LEMOS FILHO, J.P. et al. Produção e composição bromatológica do capim-marandu sob diferentes percentuais de sombreamento e doses de nitrogênio. Bioscience

Journal, v.29, n.5, 2013.

SANTIAGO-HERNÁNDEZ, F.; LÓPEZ-ORTIZ, S.; ÁVILARESÉNDIZ, C. et al. Physiological and production responses of four grasses from the genera Urochloa and Megathyrsus to shade from Meliaazedarach L. Agroforestry systems, v.90, n.2, p.339-349, 2016.

SANTOS, A.M.G.; DUBEUX JUNIOR, J.C.B.; SANTOS, M.V.F. et al. Animal performance in grass monoculture or silvopastures using tree legumes. Agroforestry Systems, p.112, 2019.

Statistical Analysis System [SAS].

SAS/STAT User's guide, Version 9.3. Cary, NC: SAS Institute Inc, 2008.

SILVA D.J.; QUEIROZ A.C. 3 ed. Análises de alimentos: métodos químicos e biológicos. Viçosa, MG: Editora UFV, 2012.

SILVA, A.B.; CARVALHO, C.A.B.; MORENZ, D.A. et al. Agricultural answers and chemical composition of Massai grass under different nitrogen doses and urea sources. Semina:

Ciências Agrárias, v.39, n.3, p.12251238, 2018.
SNIFFEN, C.J.; O'CONNOR, J.D.; VAN SOEST, P.J. et al. A net carbohydrate and protein system for evaluating cattle diets: II. Carbohydrate and protein availability. Journal of Animal Science, v.70, n.11, p.35623577, 1992.

SOUSA, L.F.; MAURÍCIO, R.M.; MOREIRA, G.R. et al. Nutritional evaluation of "Braquiarão" grass in association with "Aroeira" trees in a silvopastoral system. Agroforestry Systems, v.79, n.2, p.189-199, 2010.

VICTOR, D.M.; JANK, L.; LEMPP, B. et al. Selection of full-sib families of Panicum maximum Jacq under low light conditions. Revista Ceres, v.62, n.2, p.199-207, 2015.

WONG, C.C.; SHARUDIN, M.M.; RAHIM, H. Shade tolerance potential of some tropical forages for integration with plantations. 1. Grasses. MARDI Research Bulletin, v.13, n.3, p. 225247, 1985. 